\title{
Paradigm lost? Cross-shelf distributions of intertidal invertebrate larvae are unaffected by upwelling or downwelling
}

\author{
Alan L. Shanks ${ }^{1, *}$, R. Kipp Shearman ${ }^{2}$ \\ ${ }^{1}$ Oregon Institute of Marine Biology, University of Oregon, PO Box 5389, Charleston, Oregon 97420, USA \\ ${ }^{2}$ College of Oceanic and Atmospheric Sciences, Oregon State University, 104 COAS Administration Building, Corvallis, \\ Oregon 97331, USA
}

\begin{abstract}
We tested the hypothesis that larvae of intertidal invertebrates are swept offshore during upwelling and shoreward during downwelling. During summer 2007, vertically stratified zooplankton samples and oceanographic data were collected at 7 stations located from 0.7 to $27 \mathrm{~km}$ from shore near Coos Bay, Oregon, USA. Half the sample dates (27 June and 14 August) were characterized by upwelling conditions (lines of constant temperature and salinity tilted upward, and a band of cold surface water was against the coast) and the other half ( 3 and 18 July) were characterized by downwelling or relaxation (lines of constant temperature and salinity were flat, and warm surface waters were in contact with the shore). We identified and staged larvae of Neotrypaea californiensis, Balanus glandula, B. nubilus, Chthamalus dalli, Pollicipes polymerus, and Semibalanus cariosus/B. crenatus and identified (to species or taxa level) Mytilus californianus, M. trossulus, Hiatella arctica, Dendraster excentricus, and pinnotherid and pagurid zoea. On all sample dates, all taxa and larval stages were rare in surface waters (0 to $10 \mathrm{~m}$ depth) and, with one exception (B. nubilus cyprids), were abundant at the 3 inshore stations ( 0.7 to $4.5 \mathrm{~km}$ offshore) and very rare or absent at seaward stations. The average distance offshore of all taxa and larval stages ranged from 0.9 to $4 \mathrm{~km}$ from shore and did not vary with upwelling and downwelling. Upwelling and downwelling had no effect on the cross-shelf distribution of the larvae of intertidal invertebrates; the hypothesis that upwelling carries larvae offshore and downwelling carries them back onshore was not supported.
\end{abstract}

KEY WORDS: Larval transport - Dispersal - Recruitment . Ekman - Barnacle • Mytilus . California Current

\section{INTRODUCTION}

The hypothesis that upwelling and downwelling currents affect larval dispersal has had a large influence on the thinking of marine ecologists. Researchers believe that during upwelling, offshore flow in the surface layer (the Ekman layer) carries larvae far from shore, resulting in high larval wastage, and, in areas of persistent upwelling, they hypothesize that community structure and dynamics reflect the consequences of low larval settlement (Roughgarden et al. 1988, Alexander \& Roughgarden 1996, Connolly \& Roughgarden 1999, Broitman et al. 2001, Connolly et al.
2001). In wind-driven downwelling the reverse occurs; larvae in the surface layer are carried to shore, leading to high settlement (Farrell et al. 1991). In this dispersal scenario, larvae behave as passive particles carried along with the flow. Given that swimming speeds of many larval types (generally $\mathrm{mm} \mathrm{s}^{-1}$ ) are much slower than flow rates in the Ekman layer $\left(\mathrm{cm} \mathrm{s}^{-1}\right)$ (Barber \& Smith 1981, Chia et al. 1984), this is not an unreasonable model.

Roughgarden et al. (1988) presented the first data addressing the hypothesis, but, due to problems in the sample design, their data cannot be used to test the hypothesis (see 'Discussion' and Shanks \& Brink 2005). 
Poulin et al. (2002) found, in the wind-driven upwelling system off Chile, that larvae of an intertidal gastropod remained close to shore despite upwelling. Several studies have looked at the cross-shore distribution of larval invertebrates during wind-driven upwelling and downwelling in the mid-Atlantic Bight (Garland et al. 2002, Shanks et al. 2002, 2003a, Ma \& Grassle 2004, Ma 2005, Shanks \& Brink 2005). These researchers found taxa of larval bivalves that behaved as predicted; they were transported shoreward by downwelling and offshore by upwelling, but they also found larvae that remained below the thermocline and were transported shoreward by upwelling and offshore by downwelling, opposite to the hypothesized effect, while still other taxa remained adjacent to shore despite upwelling, downwelling, and the transition from one regime to the other. Furthermore, physical oceanographers have demonstrated that, due to physical constraints, wind-driven cross-shelf circulation shuts down near the coast, where water depths become shallow and the surface and bottom boundary layers become indistinct (Austin \& Barth 2002, Austin \& Lentz 2002, Kirincich et al. 2005); in fact, modeling suggests that cross-shelf flow near the coast during upwelling and downwelling is so reduced that passive tracers released within $2 \mathrm{~km}$ of shore may remain nearshore (Austin \& Lentz 2002). These results suggest that the current thinking on the effect of upwelling and downwelling on the cross-shelf distribution of the larvae of coastal organisms my not be correct.
Most of the recent testing of the hypothesis that upwelling and downwelling alter the cross-shelf distribution of larvae has come from studies that took place in a relatively weak upwelling system (e.g. the mid-Atlantic Bight). We tested the hypothesis that larvae are swept offshore during upwelling and shoreward during downwelling on the Oregon coast, a system with much stronger and more persistent upwelling. We sampled the larvae of intertidal invertebrates, slow-swimming larvae that should be susceptible to transport by winddriven currents. Vertically stratified zooplankton samples and oceanographic data were collected just north of Coos Bay, Oregon, during the summer upwelling season. We sampled 4 dates during the summer of 2007; half the sample dates were characterized by upwelling, the other half, by downwelling. All the larvae of intertidal invertebrates remained close to shore despite upwelling and downwelling.

\section{MATERIALS AND METHODS}

We sampled larvae of intertidal invertebrates on 4 dates during summer 2007 (Table 1). Dates were selected so that we sampled during upwelling (27 June and 14 August) and downwelling (3 and 18 July) conditions (see 'Results'). The size of the research vessel $(13 \mathrm{~m}$ ) precluded sampling during winds $>5 \mathrm{~m} \mathrm{~s}^{-1}$. On each date, a transect of 7 stations located $\sim 6 \mathrm{~km}$ north of the mouth of Coos Bay, Oregon, USA, was sampled (see

Table 1. Sample dates, station distances from shore, and depths of the stratified zooplankton samples

\begin{tabular}{|c|c|c|c|c|c|c|c|c|}
\hline \multirow{3}{*}{ Stn } & \multirow{2}{*}{\multicolumn{2}{|c|}{27 Jun }} & \multicolumn{4}{|c|}{ - Sample date } & \multirow{2}{*}{\multicolumn{2}{|c|}{-14 Aug }} \\
\hline & & & & $-3 \mathrm{Jul} \longrightarrow$ & 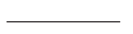 & $8 \mathrm{Jul}$ & & \\
\hline & $\begin{array}{c}\text { Distance } \\
\text { offshore } \\
(\mathrm{km})\end{array}$ & $\begin{array}{l}\text { Sample } \\
\text { intervals } \\
(\mathrm{m})\end{array}$ & $\begin{array}{c}\text { Distance } \\
\text { offshore } \\
(\mathrm{km})\end{array}$ & $\begin{array}{l}\text { Sample } \\
\text { intervals } \\
(\mathrm{m})\end{array}$ & $\begin{array}{c}\text { Distance } \\
\text { offshore } \\
(\mathrm{km})\end{array}$ & $\begin{array}{l}\text { Sample } \\
\text { intervals } \\
(\mathrm{m})\end{array}$ & $\begin{array}{c}\text { Distance } \\
\text { offshore } \\
(\mathrm{km})\end{array}$ & $\begin{array}{l}\text { Sample } \\
\text { intervals } \\
(\mathrm{m})\end{array}$ \\
\hline 1 & 0.7 & $\begin{array}{l}\text { Neuston, } \\
0-5,5-10\end{array}$ & 0.7 & $\begin{array}{l}\text { Neuston, } \\
0-6,6-13\end{array}$ & 0.7 & $\begin{array}{l}\text { Neuston, } \\
12-25\end{array}$ & 0.5 & $\begin{array}{l}\text { Neuston, } \\
0-5,5-9\end{array}$ \\
\hline 2 & 2.9 & $\begin{array}{c}\text { Neuston, } \\
0-8,8-16,16-25\end{array}$ & 2.8 & $\begin{array}{c}\text { Neuston, } \\
0-12,12-18,18-28\end{array}$ & 1.8 & $\begin{array}{c}\text { Neuston, } \\
0-10,10-28\end{array}$ & 2.0 & $\begin{array}{c}\text { Neuston, } \\
0-10,10-18\end{array}$ \\
\hline 3 & 4.7 & $\begin{array}{c}\text { Neuston, } \\
0-12,12-18 \\
18-28,28-40\end{array}$ & 5.6 & $\begin{array}{c}\text { Neuston, } \\
0-16,16-30 \\
30-40,40-70\end{array}$ & 6.8 & $\begin{array}{c}\text { Neuston, } \\
0-15,15-30 \\
30-45,45-70\end{array}$ & 5.0 & $\begin{array}{c}\text { Neuston, } \\
0-8,8-20 \\
20-40,40-50\end{array}$ \\
\hline 4 & 9.6 & $\begin{array}{c}\text { Neuston, } \\
0-15,15-30 \\
30-40,40-70\end{array}$ & 11.1 & $\begin{array}{c}\text { Neuston, } \\
0-15,15-30 \\
30-40,40-70\end{array}$ & 13.8 & $\begin{array}{c}\text { Neuston, } \\
0-15,15-30 \\
30-40,40-70\end{array}$ & 11.9 & $\begin{array}{c}\text { Neuston, } \\
0-10,10-20 \\
20-50,50-70\end{array}$ \\
\hline 5 & 16.6 & $\begin{array}{c}\text { Neuston, } \\
0-15,15-25 \\
25-40,40-60\end{array}$ & 16.7 & $\begin{array}{c}\text { Neuston, } \\
0-15,15-30 \\
30-40,40-70\end{array}$ & 18.4 & $\begin{array}{c}\text { Neuston, } \\
0-15,15-25 \\
25-40,40-70\end{array}$ & 17.2 & $\begin{array}{c}\text { Neuston, } \\
0-7,7-25 \\
25-50,50-70\end{array}$ \\
\hline 6 & 22.3 & $\begin{array}{c}\text { Neuston, } \\
0-10,10-30 \\
30-40,40-60\end{array}$ & 22.2 & $\begin{array}{c}\text { Neuston, } \\
0-15,15-30 \\
30-45,45-60\end{array}$ & 25.0 & $\begin{array}{c}\text { Neuston, } \\
0-15,15-25 \\
25-45,45-70\end{array}$ & 23.8 & $\begin{array}{c}\text { Neuston, } \\
0-15,15-30 \\
30-60,60-70\end{array}$ \\
\hline 7 & 27.8 & $\begin{array}{c}\text { Neuston, } \\
0-10,10-15 \\
15-40,40-60\end{array}$ & 27.8 & $\begin{array}{c}\text { Neuston, } \\
0-15,15-30 \\
30-40,40-70\end{array}$ & 28.0 & $\begin{array}{c}\text { Neuston, } \\
0-15,15-25 \\
25-45,45-70\end{array}$ & 27.7 & $\begin{array}{l}\text { Neuston, } \\
0-5,5-25\end{array}$ \\
\hline
\end{tabular}


Fig. 2). The most inshore station was 0.5 to $0.7 \mathrm{~km}$ from shore, and the most offshore station was $28 \mathrm{~km}$ offshore. The spacing of the 5 stations in between varied with date such that we would sample to either side of oceanographic features apparent in satellite images available prior to each cruise. Station location was determined with a global positioning system (GPS), and distance from shore, with the radar on the research vessel. At each station, we made a conductivity, temperature, depth (CTD) cast with a SeaBird Model 19 CTD and collected stratified zooplankton samples through the water column. Data from the CTD casts were used to determine the zooplankton sample depths. At stations with bottom depths $\geq 70 \mathrm{~m}, 5$ depths were sampled: 2 were below the thermocline and 1 each in the thermocline, the mixed layer, and the neuston. The deepest tows were to $70 \mathrm{~m}$. At shallower stations, 3 or 4 strata were sampled: the neuston in all cases, above and below the thermocline at the most nearshore station, and below, in and above the thermocline at slightly deeper stations. On each date the pattern of sampling was the same. Sunrise varied from 05:39 h (27 June) to 06:23 h (14 August), and we commenced sampling at the most offshore station at least $1 \mathrm{~h}$ after sunrise. We completed sampling at the most inshore station at around 15:30 $h$; all sampling occurred during daylight. At the deeper stations, where we sampled 5 depth strata, procedures at each station took a bit less than an hour to complete, and at the shallow stations sampling took about half an hour.

The neuston samples were made with a Manta net $(1 \times 0.2 \mathrm{~m}$, with $330 \mu \mathrm{m}$ mesh). The mesh on the neuston net was fine enough to capture late larval stages, but was too course to capture the early larval stages of some species. The net retained all larval stages of decapods: Stage IV nauplii and all later stages of the barnacles Balanus glandula, B. nubilus, Semibalanus cariosus, and B. crenatus, and cyprids and Stage VI nauplii and cyprids of Chthamalus dalli and Pollicipes polymerus. Tows were $5 \mathrm{~min}$ in duration, and a flow meter mounted in the net was used to calculate the volume filtered (filtered volume ranged from 40 to $150 \mathrm{~m}^{3}$ ). The water column samples were collected with a small Tucker trawl $(0.25 \times 0.25 \mathrm{~m}$, with $202 \mu \mathrm{m}$ mesh). The mesh size for the Tucker trawl was selected to be large enough to allow most of the phytoplankton to pass through the net, but small enough to retain larval invertebrates. The mesh was fine enough to retain all stages of decapod and barnacle larvae, but retained only those mytilid larvae that were close to metamorphosis. The net was equipped with a messenger-activated release, allowing nets to be opened and closed at depth. Flow meters in the nets were used to determine the volume filtered (filtered volume ranged from 5 to $20 \mathrm{~m}^{3}$ ). Tows were 3 to $5 \mathrm{~min}$ long; when phytoplankton abundance was high, tows were shorter in duration to avoid net clogging. Sample depth was determined by the standard technique of measuring wire angle and the amount of wire out. On several cruises, calculated sample depths were compared to depths recorded with a Vemco time/pressure recorder; calculated and measured depths were similar.

Zooplankton samples were preserved in the field with buffered formalin. In the laboratory, the samples were washed free of formalin on a $53 \mu \mathrm{m}$ sieve. The sample was transferred to a $300 \mathrm{ml}$ beaker and, with the aid of an electronic balance, made up to $200 \mathrm{ml}$ $(200 \mathrm{~g})$. The sample was homogenized by vigorous random stirring, and subsamples were removed with a Stempel pipette (Peterson et al. 1979, Omori \& Ikeda 1984). Subsamples were counted until at least 100 individuals of the most common organisms had been enumerated. This yielded a sample standard deviation of approximately $10 \%$ for the most abundant organisms and between 10 and $20 \%$ for the less common species (Venrick 1978). No statistically significant differences were found between the numbers of organisms determined by subsampling and by counting the whole sample; the subsampling technique adequately described the samples (Shanks et al. 2002).

Samples were inspected with an inverted compound microscope at $40 \times$ and, when needed for identification, 100x. The higher magnification available with the inverted microscope relative to a dissecting microscope greatly facilitated the accurate identification of species and stages. Species, taxa, and larval stages were identified using identification keys in (Shanks 2001). We identified, staged, and counted the larvae of Neotrypaea californiensis (the ghost shrimp) and all the common intertidal barnacles, Balanus glandula, B. nubilus, Chthamalus dalli, Pollicipes polymerus, and Semibalanus cariosus/B. crenatus (these species were too difficult to tell apart and were therefore combined). There are few descriptions of west coast bivalve larvae, and we were only able to identify unambiguously the larvae of Mytilus californianus, M. trossulus, and Hiatella arctica $(H$. arctica, the gaper clam, was only present on 27 June). We counted pinnotherid and pagurid zoea, but did not identify the larvae to species or stage. The larvae of Dendraster excentricus were present on 2 dates (27 June and 3 July).

Hourly wind data were obtained from the NOAA Port Orford, Oregon, weather buoy (Station 46015, $42.76^{\circ} \mathrm{N}, 124.83^{\circ} \mathrm{W}$ ), which is the closest buoy to the sample site and is located $30 \mathrm{~km}$ offshore and about $85 \mathrm{~km}$ south of the study site. During the upwelling season, winds along the length of the Oregon continental shelf are generally very similar (Strub et al. $1987 \mathrm{a}, \mathrm{b})$. Daily upwelling index values for $42^{\circ} \mathrm{N}$, $125^{\circ} \mathrm{W}$ were obtained from the Pacific Fisheries Environmental Laboratory website (www.pfeg.noaa.gov). 
Satellite images of sea surface temperature were obtained from Terrafin (www.terrafin.com), which provides enhanced images from the NOAA Polar Orbiting satellites. Contour plots of the distribution of the biological and physical data were made using Noesys Transform contour plotting program, with the kriging option for gridding and interpolating.

If larvae are pushed offshore by upwelling and carried back toward shore by downwelling, then, on a sample date, the average distance offshore for a larval type should correlate with the amount of upwelling or downwelling they had recently experienced. We calculated the average distance offshore for each taxon/larval stage by first calculating the number of individuals per square meter (no. $\mathrm{m}^{-2}$ ) at each station and then using these values in the following equation: avg. distance $=\Sigma\left(\right.$ no. $\mathrm{m}^{-2}$ $\times$ distance offshore for each station $) /\left(\Sigma\right.$ no. $\left.\mathrm{m}^{-2}\right)$. An ANOVA was then used to statistically test the hypothesis that the average distance offshore varied with upwelling and downwelling. Species were divided into 2 groups: rocky intertidal species (Mytilus trossulus, M. californianus, Balanus glandula, Chthamalus dalli, Pollicipes polymerus, and Semibalanus cariosus/B. crenatus) and non-rocky intertidal taxa (B. nubilus, Neotrypaea californiensis, and pinnotherid and pagurid zoea) and separate ANOVAs were run on each set of data. In those species that were identified to stage, we used the most advanced developmental stage that was present on all sample dates (Stage V nauplii for barnacles and Stage II for $N$. californiensis). The ANOVA tested for species and upwelling/downwelling (dates were replicates for each hydrographic condition) effects on the average distance offshore. The data were not normally distributed, so they were log transformed, after which the distributions were not significantly different from a normal distribution. The power of the analysis was determined using the program GPower3 (Faul et al. 2007).

\section{RESULTS}

\section{Physical oceanography}

Upwelling was occurring on 27 June and 14 August. During the $5 \mathrm{~d}$ prior to the sample dates, the upwelling index was mostly positive and the average south- ward (approximately along-shelf) winds were $3.9 \mathrm{~m} \mathrm{~s}^{-1}$ preceding 27 June and $3.6 \mathrm{~m} \mathrm{~s}^{-1}$ preceding 14 August (Fig. 1). Cloud-free satellite images of sea surface temperature were available for 14 August, but 27 June was overcast and we used an image from 26 June. In satellite images of sea surface temperature (Fig. 2) upwelling is clearly apparent as a band of cold water along the coast with warmer waters offshore. On 27 June, the topography of the boundary between the cold upwelled and the warmer offshore waters was fairly simple, while on 14 August it was characterized by jets of cold water and eddies offshore. Contour plots of the oceanographic data collected on these dates also indicate that upwelling was occurring; in these plots the lines of constant temperature and salinity are tilted toward the surface on the landward side of each transect (Fig. 3). Surface salinity and temperature at the
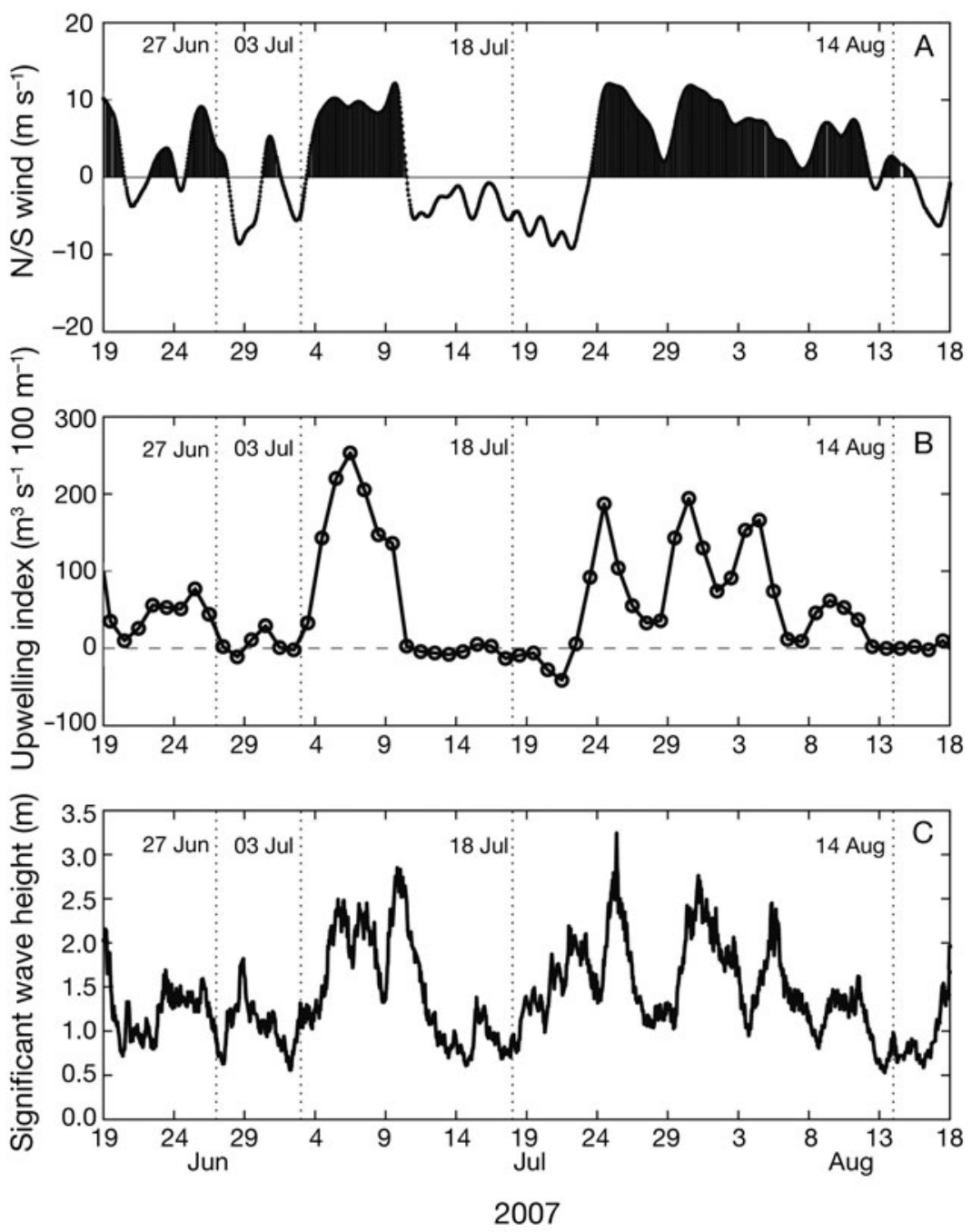

Fig. 1. (A) North-south wind speed during summer 2007 (positive values are from the north, negative values from the south). (B) Daily upwelling index calculated for $42^{\circ}$ N. (C) Hourly significant wave height. Sampling dates are indicated by vertical dotted lines 

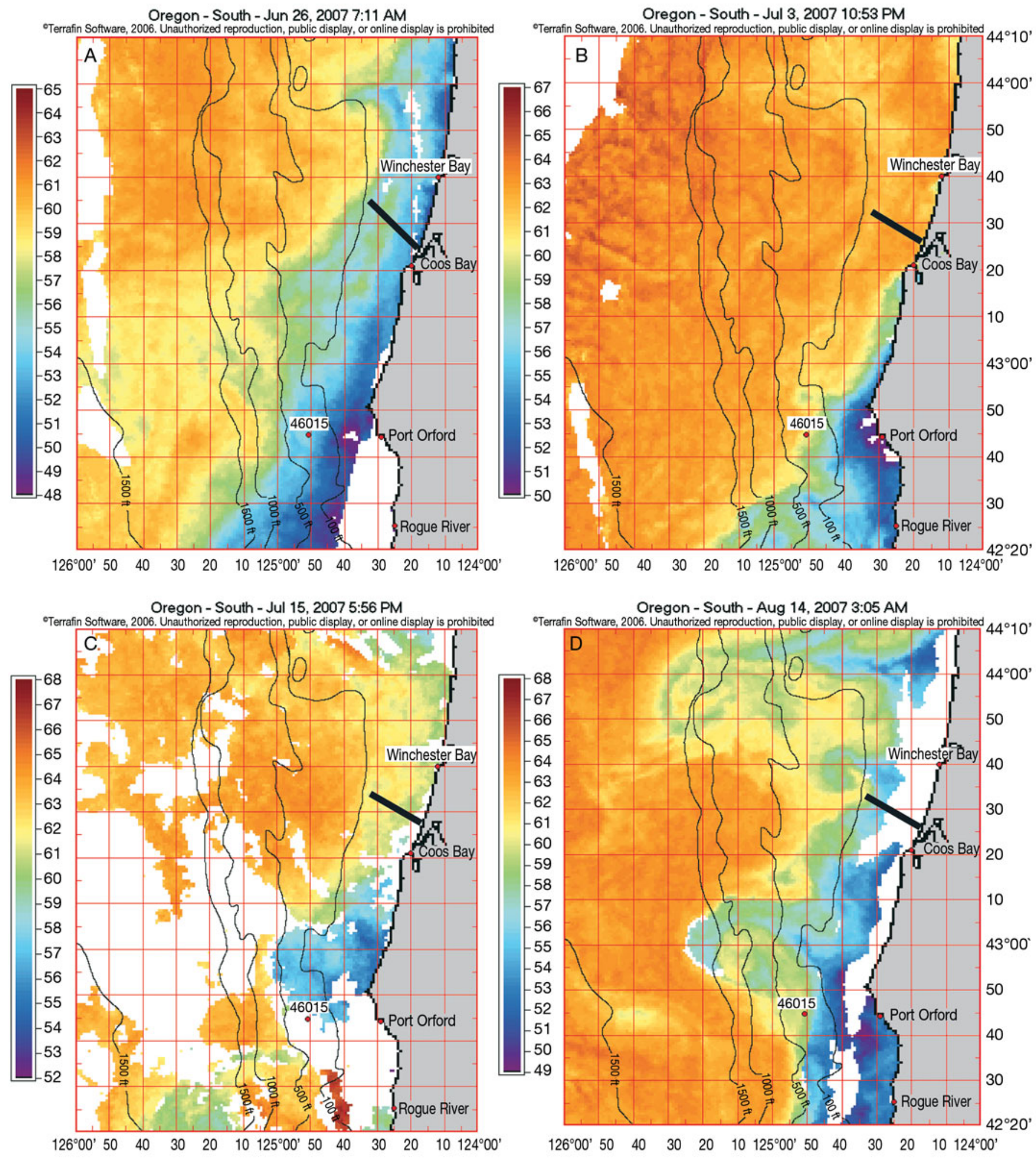

Fig. 2. Satellite images of sea surface temperature taken during summer 2007. Images are from relatively cloud-free days closest to the sample date. Transects (thick black lines in each figure) extended due west approximately $27 \mathrm{~km}$ from about $43^{\circ} 24^{\prime} \mathrm{N}$, $124^{\circ} 19^{\prime} \mathrm{W}$. Upwelling was occurring on 26 June and 14 August (A and D) as indicated by the band of colder (blue colors) water against the coast. On 3 and 15 July (B and C), downwelling was occurring in the sample area, as indicated by the warmer (yellow orange colors) water present against the shore. Depth contours are in feet $(1 \mathrm{~m}=3.25 \mathrm{ft})$, temperatures are in Fahrenheit $\left(52^{\circ} \mathrm{F}=11.1^{\circ} \mathrm{C}, 68^{\circ} \mathrm{F}=20.0^{\circ} \mathrm{C}\right)$ 
most inshore station were between 33.0 and 33.5 and 10 and $12^{\circ} \mathrm{C}$, respectively. On both dates, the thermocline was bent upward and contacted the surface. This contact zone, the upwelling front, separated the upwelled waters against the coast, and the displaced warmer surface waters were located $\sim 7 \mathrm{~km}$ offshore on 27 June and $\sim 10 \mathrm{~km}$ offshore on 14 August. On both dates, landward of the upwelling front, and especially at the most nearshore stations, the water column was more weakly stratified than seaward of the front where stratification was stronger (Fig. 4).
During the $5 \mathrm{~d}$ prior to the samplings on 3 and 18 July, the alongshore wind was from the south, with average speeds of $-2.5 \mathrm{~m} \mathrm{~s}^{-1}$ (3 July) and $-3.1 \mathrm{~m} \mathrm{~s}^{-1}$ (18 July), and the upwelling index was near zero (Fig. 1). Cloud-free satellite images of sea surface temperature were available for 3 July, but not for 18 July. The image from 15 July is the closest to the 18 July sample date; however, this photo was taken during the period of south winds and near 0 upwelling index, the same conditions as on 18 July (Fig. 1). In these satellite images, the nearshore band of cold upwelled water
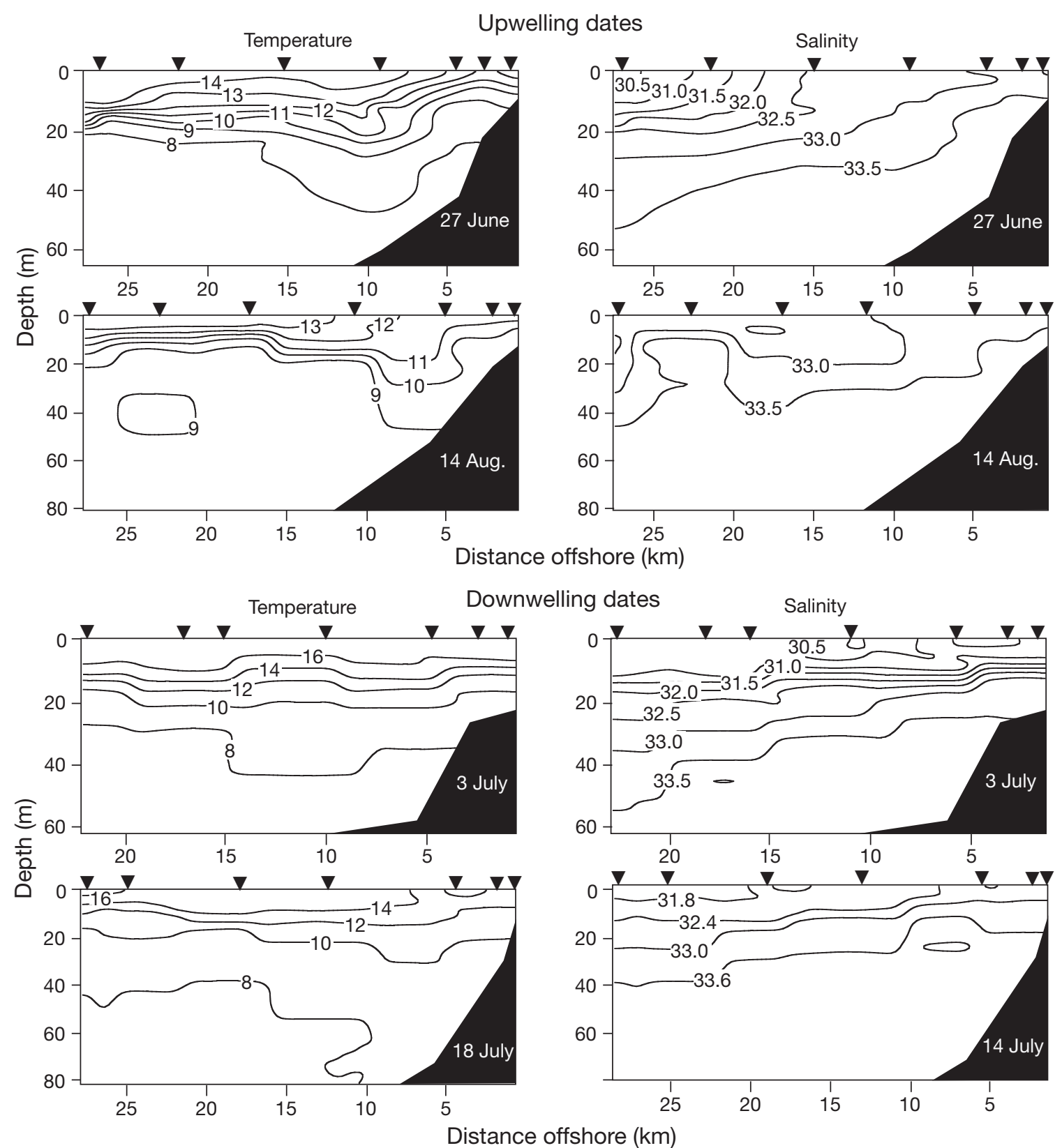

Fig. 3. Contour plots of constant temperature and salinity during sampling dates with upwelling and downwelling. Upwelling is indicated by the upward tilt of the contour lines toward the shore, while downwelling/relaxation is indicated by downward tilting or horizontal contour lines. $\mathbf{\nabla}$ : approximate locations of stations 

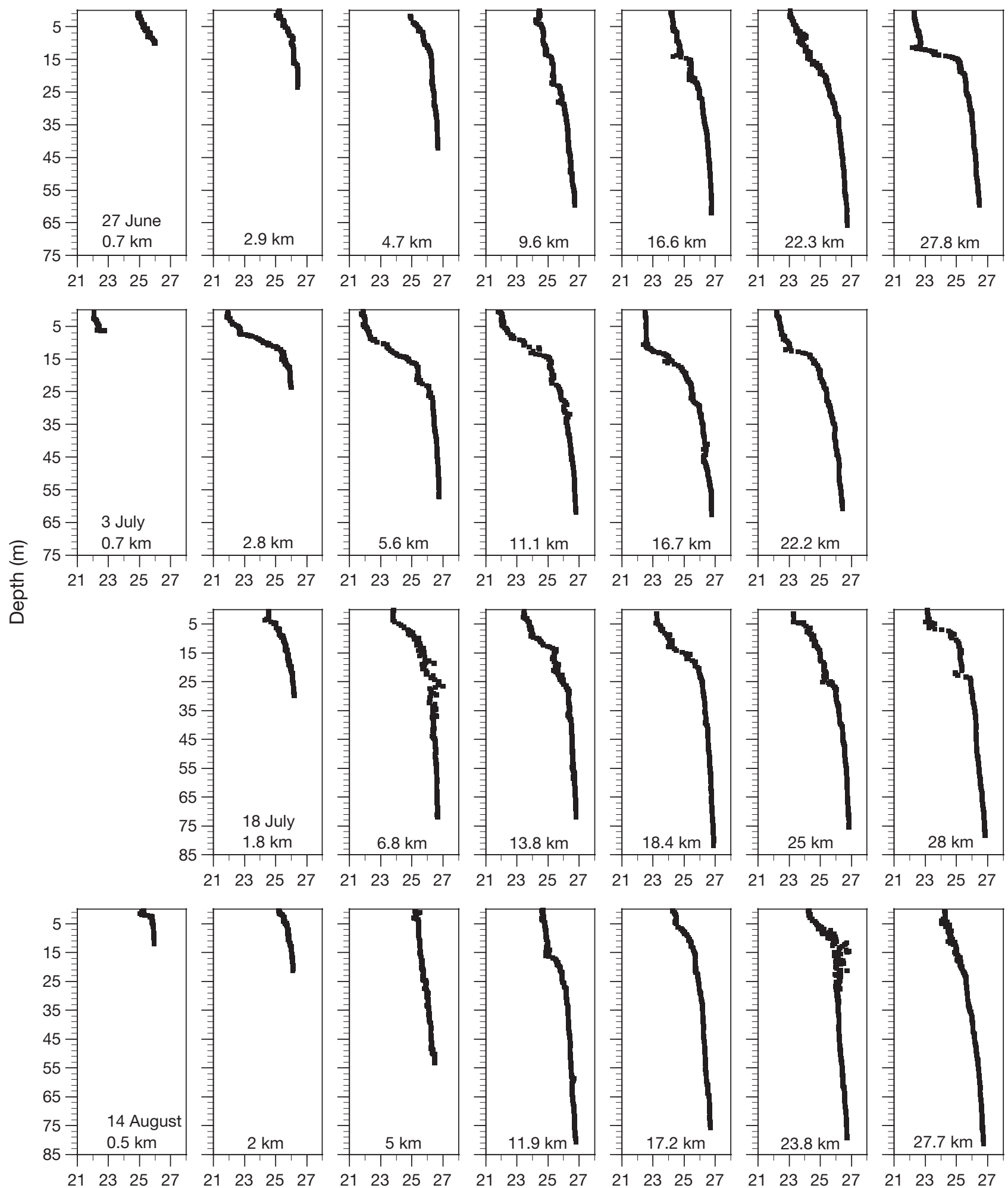

Density, Sigma t

Fig. 4. The vertical distribution of density (sigma t) on each sampling date (horizontal rows of panels) along the transects of stations. Upwelling was occurring on 27 June and 14 August and downwelling was occurring on 3 and 18 July 
present in the photographs from 27 June and $14 \mathrm{Au}-$ gust is absent and is replaced by warmer offshore waters adjacent to the coast. Due to various problems, CTD data from Stn 7 on 3 July and Stn 1 on 18 July were lost. In the contour plots of the oceanographic data collected on these dates, the lines of constant temperature and salinity are nearly horizontal, the thermocline was not bent upward and did not contact the surface, and surface temperatures and salinity at the most inshore station were between 16 and $13^{\circ} \mathrm{C}$ and $<33.0$, respectively.

Water column stratification was stronger during downwelling events than during upwelling; during downwelling on 3 and 18 July the difference in density across the water column at Stn 2 was 4 and 1.6 sigma t, respectively, while on 27 June and 14 August it was only 1 and 0.9, respectively (Fig. 4). Often during a downwelling event the pycnocline is bent downward and contacts the bottom some distance from shore (e.g. Austin \& Lentz 2002). The point at which the pycnocline contacts the bottom is known as the downwelling front, and landward of the front the water column is mixed. On 3 and 18 July, the pycnocline did not do this; there was no downwelling front, and the water column remained stratified even at the most inshore station. This suggests that on these dates downwelling was weak.

The most inshore station on the sample transect was located $\sim 6 \mathrm{~km}$ north of the mouth of the Coos estuary (Fig. 2). During ebb tides a plume of low-density water forms around the mouth of the estuary, and this plume may have influenced the observed hydrography. In summer, when there is little rain, the plume is small, and, during upwelling winds, the plume is pushed southward and would not enter the study area. With the southern winds of downwelling, however, the plume would be pushed northward toward the study area. If the plume had been present on downwelling days, we would have observed a shallow lens of lowsalinity water at the most inshore stations, but this was not observed (Fig. 3); the plume did not influence the observations.

\section{Biology}

The abundance of larvae was highest on the first sample date and decreased through the summer (for example, Fig. 5); with only 4 sample dates this should not, however, be interpreted as strong evidence for a seasonal trend. On all sample dates, larvae (all taxa and larval stages) were caught at the 3 stations closest to shore. At Stns 1 through 3, 1000s of larvae were enumerated on each date, but seaward of Stn 3 (about $6 \mathrm{~km}$ offshore) only 4, 0, 25, and 0 larvae (all taxa and larval stages summed from all of the tows made beyond Stn 3) were enumerated on 27 June, 3 and 18 July, and 14 August, respectively. On all sample dates, larvae of all taxa and stages enumerated were abundant within $5 \mathrm{~km}$ of shore and nearly absent from the waters beyond $5 \mathrm{~km}$.

The vertical distribution of larvae was consistent across taxa, developmental stage, and the 4 sample dates. Typical distributions are displayed in Fig. 5. At the 3 inshore stations, larvae (all taxa and larval stages) were extremely rare in the neuston samples and were present at very low concentrations in the near surface plankton tows. At Stns 1 and 2, the most inshore stations, larval concentrations were always highest in the tows just above the bottom at depths of around 5 to $10 \mathrm{~m}$ (Stn 1) and 15 to $25 \mathrm{~m}$ (Stn 2). At Stn 3, larvae were caught at low concentrations in the near bottom tows (depths of around 30 to $40 \mathrm{~m}$ ) and were most abundant at intermediate depths of around 20 to $30 \mathrm{~m}$. Larvae avoided the surface layer and were concentrated either adjacent to the bottom (station depths $<25 \mathrm{~m}$ ) or at intermediate depths $(20$ to $30 \mathrm{~m}$ ) at Stn 3 .

Contour plots for each taxon, larval stage and date were produced ( $>140$ contour plots). Inspection of these plots suggested that there was no consistent difference in the distribution of larvae during upwelling and downwelling events. To illustrate this, a small subset of these contour plots are presented in Fig. 5. For these plots, 3 taxa were selected that are especially common and ecologically important in the intertidal zone (Mytilus trossulus, Balanus glandula, and Semibalanus cariosus/B. crenatus). We plotted the distribution of Stage IV barnacle larvae because, by this stage of development, larvae have been pelagic for several weeks, and cross-shelf currents should have caused extensive dispersal. Furthermore, this larval stage was relatively abundant throughout the summer.

On each date, whether upwelling or downwelling was occurring, the larvae were present as a distinct subsurface cloud defined by samples from the most inshore 3 stations. The distributions of Balanus glandula Stage IV on 14 August (upwelling) and Mytilus trossulus on 18 July (downwelling) extended beyond $5 \mathrm{~km}$ from shore; otherwise, larval distributions were within $5 \mathrm{~km}$ of shore (Fig. 5). Beyond $10 \mathrm{~km}$ from shore (beyond Stn 3), the larvae of intertidal invertebrates were extremely rare or absent. The distributions of the different larval types on a given date were often surprisingly similar. For example, the distributions of M. trossulus and Semibalanus cariosus/B. crenatus on 27 June and $M$. trossulus and B. glandula on 3 July were nearly identical.

The contour plots indicated that during upwelling and downwelling conditions larvae were distributed close to shore. To further investigate this relationship, 
Upwelling

Mytilus trossulus

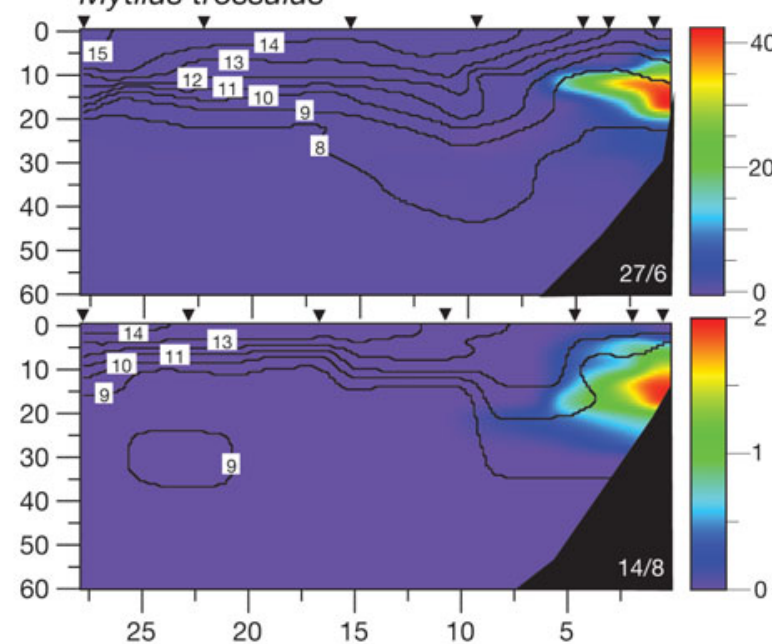

Balanus glandula Stage IV

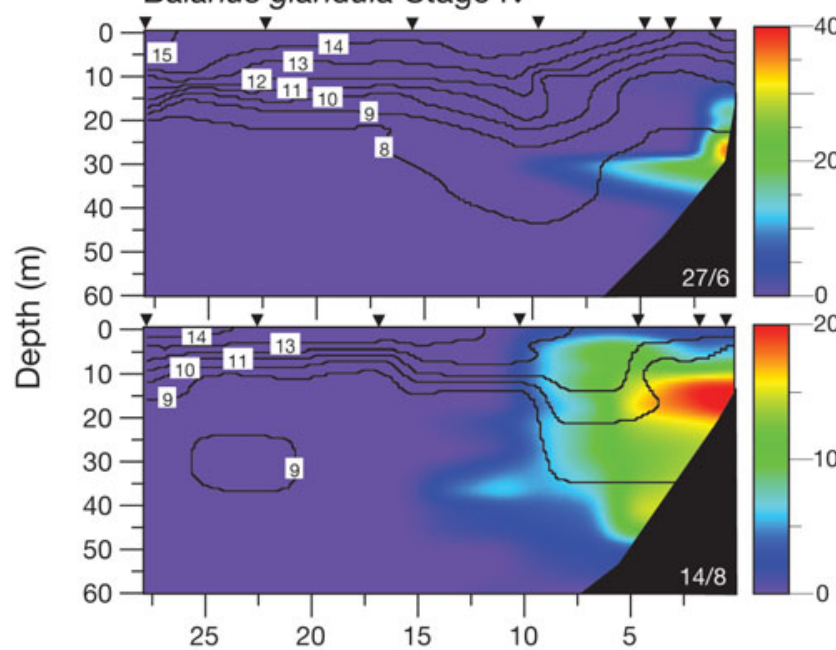

Semibalanus cariosus/Balanus crenatus Stage IV

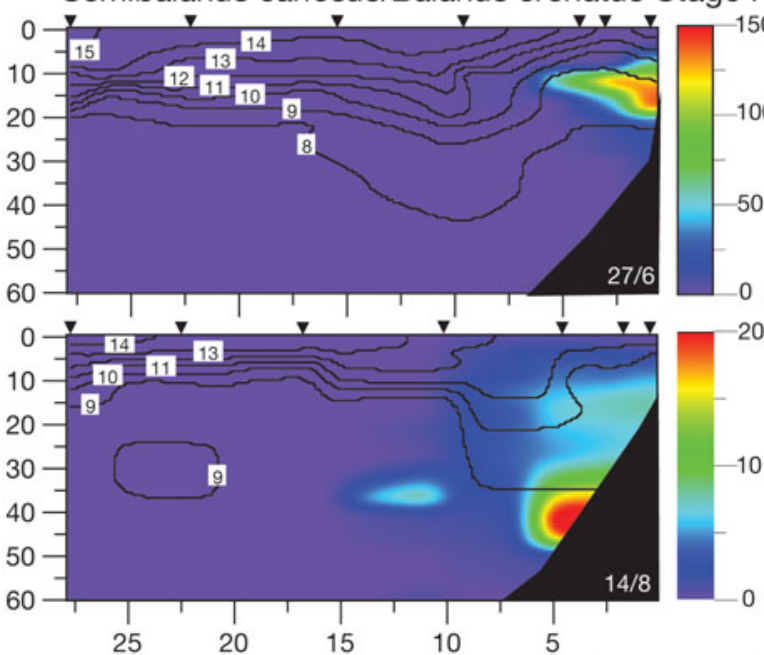

Downwelling
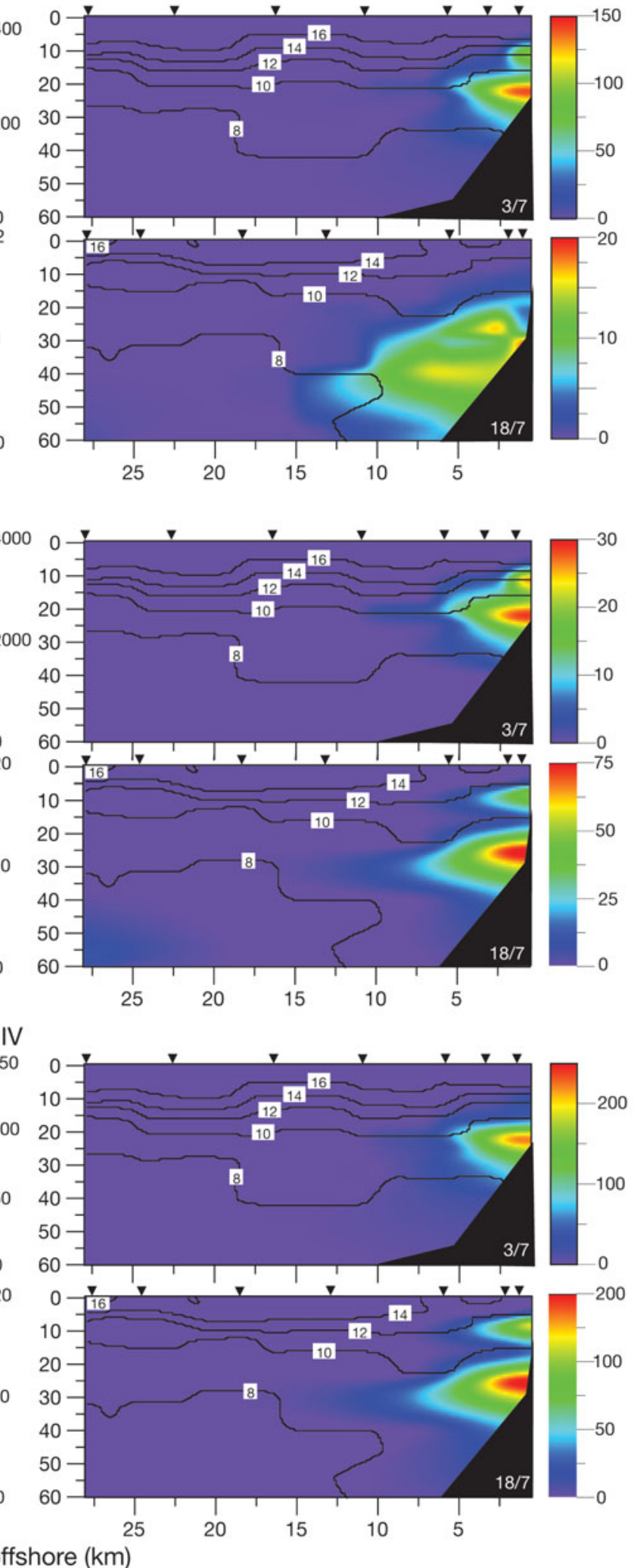

Fig. 5. Representative contour plots of typical larval distributions. Values in color are larval concentrations $\left(\right.$ no. $\left.\mathrm{m}^{-3}\right)$, while the contour lines are lines of constant temperature. $\mathbf{\nabla}$ : approximate locations of stations 
we plotted the average distance offshore for all taxa and larval stages against the summed daily upwelling index over the $5 \mathrm{~d}$ prior to the sample date (Fig. 6); larvae were not distributed further offshore during upwelling or closer to shore during downwelling. We statistically tested this observation with an ANOVA and found no significant effect of species, upwelling/ downwelling, or the interaction of these 2 variables on the average distance offshore of the larvae of rocky intertidal and non-rocky intertidal taxa (Table 2).

Our sample set is relatively small (2 upwelling and downwelling dates), so perhaps the lack of a significant difference in the distance larvae were found from shore on upwelling and downwelling dates is due to a lack of statistical power. Using the program $\mathrm{G}^{*}$ Power3, we ran a post hoc power analysis. The effect size was calculated from the observed variance of the logtransformed data used in the ANOVA. Powers $(1-\beta$ error probability) for the rocky intertidal and nonrocky intertidal taxa analyses were 0.99 and 0.96, respectively. Despite a relatively small sample size, power was high. This was due to the low variance in the distance the different larval taxa were found offshore during both hydrographic conditions. This leads to the conclusion that there was no statistically significant effect of upwelling- or downwelling-favorable winds on the cross-shelf distribution of the larvae.

The only taxon/larval stage whose distribution appeared to have been affected by upwelling and downwelling was Balanus nubilus cyprids. B. nubilus cyprids were further offshore during downwelling (19 and $11 \mathrm{~km}$ offshore) than during upwelling (6 and $4 \mathrm{~km}$ offshore). agic primarily during the upwelling season. Spawning in Mytilus californianus and M. trossulus occurs over a longer period, but a large fraction of the larvae produced annually develop during the upwelling season (Morris et al. 1980). The fact that many of the intertidal invertebrates and fishes in the California Current system spawn during the upwelling season (Shanks \& Eckert 2005) suggests that they may have evolved the capacity to avoid offshore transport of their larvae by upwelling currents and the ensuing larval wastage.

The hydrographic data clearly indicate that sampling on 27 June and 14 August occurred during upwelling, while sampling on 3 July and 8 July took place during downwelling or relaxation from upwelling. On upwelling days, satellite images of sea surface temperature displayed the characteristic band of cold water against the coast and, in contour plots of CTD data, the lines of constant temperature and salinity tilted upward toward the surface on the landward side of the transects. An upwelling front was present on both dates at distances of $>7 \mathrm{~km}$ from shore. On downwelling/relaxation days, satellite images indicated that warm water was up against the coast, and, in the contour plots, lines of constant temperature and salinity were nearly horizontal. The zooplankton sampling along the transects was quite detailed: on each date we sampled 7 stations between $<1$ and $28 \mathrm{~km}$ offshore and at each station we sampled from 3 to 6 depths ( 37 depth-stratified samples per transect). These samples allow us to test the hypothesis that larvae are swept offshore by upwelling and onshore by downwelling.

\section{DISCUSSION}

In the California Current system, winter winds tend to be from the south, favoring downwelling. In the spring, atmospheric high and low pressure cells over the North Pacific shift, and winds begin to blow relatively persistently from the north, favoring upwelling. This is known as the spring transition. Upwelling-favorable winds generally are dominant into the fall when the weather shifts back to typical winter conditions. All the crustaceans whose larvae were enumerated are spring/summer spawners (Morris et al. 1980); they spawn during the upwelling season, and pelagic larval development lasts several weeks (Shanks $\&$ Eckert 2005). Hence, larvae are pel-
Table 2. Results of ANOVA comparing the log-transformed average distance offshore of the larvae of rocky and non-rocky intertidal invertebrate species to the strength of upwelling and downwelling (summed upwelling index over the $5 \mathrm{~d}$ prior to the sample date). A post hoc power analysis, in which the effect size was calculated from the observed variance, indicated that powers (1- $\beta$ error probability) for the rocky intertidal and non-rocky intertidal ANOVAs were 0.99 and 0.96 , respectively. NS: not significant

\begin{tabular}{|lrllll|}
\hline & df & SS & MS & $F$ & \\
\hline Rocky intertidal taxa & & & & & \\
Upwelling/Downwelling & 1 & 0.00007 & 0.00007 & 0.00002 & NS \\
Species & 5 & 0.06 & 0.012 & 0.0035 & NS \\
Interaction & 5 & 0.22 & 0.04 & 0.013 & NS \\
Within-group error & 12 & 41.7 & 3.44 & & \\
Total & 23 & 1.9 & & & \\
& & & & & \\
Non-rocky intertidal taxa & & & & 0.08 & NS \\
Upwelling/Downwelling & 1 & 0.008 & 0.008 & 0.0029 & NS \\
Species & 3 & 0.69 & 0.23 & \\
Interaction & 3 & 0.082 & 0.027 & 0.0098 & NS \\
Within-group error & 8 & 22.43 & 2.8 & & \\
Total & 16 & 1.7 & & & \\
\hline
\end{tabular}




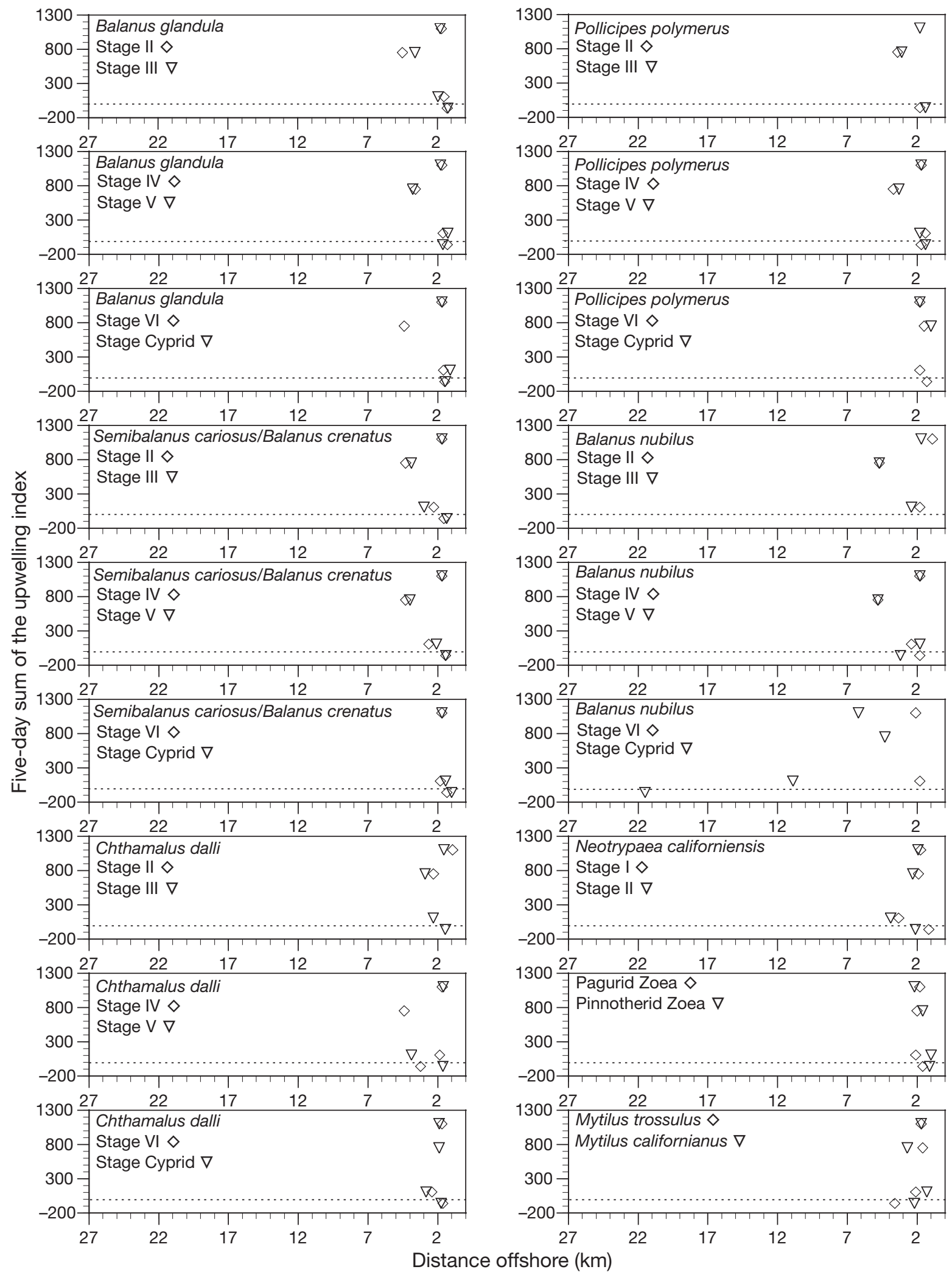

Fig. 6. The average distance offshore for each taxon and larval stage for all the larval invertebrates enumerated in the present study, plotted against the summed daily upwelling index (positive values indicate upwelling, negative values downwelling) over the $5 \mathrm{~d}$ before the sample date 
The meshes on the Tucker trawl and neuston net were different (202 and $330 \mu \mathrm{m}$, respectively) and were not fine enough to retain all stages of intertidal invertebrate larvae. The selected net meshes were a compromise between adequate sampling of larvae and the need to avoid clogging of the nets by the largechain-forming diatoms common in Oregon coastal waters during the upwelling season. The mesh on the Tucker trawl was fine enough to retain all larval stages of crustaceans, but only retained late stage bivalve larvae. The inability to capture early stage bivalve larvae is unfortunate, but a net mesh fine enough to capture the early larval stages would have rapidly clogged with phytoplankton. The courser mesh of the neuston net was capable of retaining all larval stages of decapods, cyprids, and, depending on taxon, most or some of the naupliar stages of barnacles. The larval types that could be retained by the neuston net were very rare in the neuston tows (e.g. no barnacle nauplii were caught and few cyprids), indicating low larval concentrations and avoidance of the neuston during the day. The Tucker trawl samples indicated that the larvae of intertidal invertebrates were absent from the surface waters below the neuston as well. Both the neuston and Tucker trawl samples indicated that larvae avoided surface waters; hence, the difference in net mesh had little effect on the determination of the vertical and cross-shelf distributions of larvae.

The idea that upwelling transports larvae offshore and downwelling carries them back shoreward is based upon the observation that the swimming speed of most larval types is much slower than the cross-shelf current speeds associated with upwelling and downwelling. During upwelling, surface waters (the upper 10 to $20 \mathrm{~m}$ ) are carried offshore by wind-driven Ekman transport and, beneath this layer there is a shoreward flow that replaces the water carried offshore. During downwelling the flow is reversed. If the larvae of intertidal organisms are to be carried offshore by upwelling they must reside in the surface Ekman layer, as it is this layer that moves offshore with upwelling and onshore with downwelling. The advection of larvae below the surface Ekman layer should be reversed.

During the entire study, larvae of intertidal invertebrates were nearly absent from the surface waters. The highest concentrations were consistently found in the deepest tows at the 2 stations closest to shore and at Stn 3 at depths of around 20 to $30 \mathrm{~m}$. Rilov et al. (2008), using larval collectors mounted on nearshore moorings, report similar results; mussel larvae off Oregon and New Zealand were more abundant at mid-water depths than those either near the surface or bottom. Off Duck, North Carolina, in late summer, mussel larvae were also found below the pycnocline (Shanks et al. 2002, 2003a). Sampling of meroplankton off north- ern California, sampling similar to that reported here, also found that the larvae of nearshore invertebrates avoided the surface waters (Morgan et al. 2009, in press). By avoiding surface waters, larvae should not be carried seaward by upwelling. During upwelling relaxation, as the upwelling front propagates to shore, larvae present in the surface waters can be transported shoreward (Shanks et al. 2000). However, the intertidal invertebrate larvae were not present in the surface waters, hence, shoreward transport by the upwelling front relaxing to shore is unlikely. By inhabiting the deeper strata in the water column they should have been carried offshore by downwelling and onshore by upwelling, but the average distance larvae were found from shore remained unchanged, indicating that this did not happen.

There were no consistent differences in the distributions of larvae on the 4 sample dates. No matter what the conditions, all taxa and larval stages were present at the most inshore station and their distributions extended out to the third station from shore; beyond the third station larvae of intertidal invertebrates were exceedingly rare. The entire development of these larvae was confined to the waters within about $5 \mathrm{~km}$ of shore; with one exception, the average distance offshore for all taxa and larval stages was $\leq 5 \mathrm{~km}$ and was mostly $<3 \mathrm{~km}$. The cross-shelf distribution of the larvae of intertidal invertebrates did not vary with upwelling and downwelling; the hypothesis clearly failed the test.

Balanus nubilus cyprids were further offshore during downwelling than during upwelling; unlike all the other taxa/larval stages, their distribution suggests they may have been transported offshore by downwelling currents. All the species of barnacles that remained near the coast during upwelling and downwelling have adult distributions in the intertidal zone. $B$. nubilus adults are found from the low intertidal to $90 \mathrm{~m}$ depth (Morris et al. 1980). B. nubilus cyprids carried away from shore by downwelling currents would be transported across potential subtidal benthic settlement sites.

During upwelling, the center of distribution of all taxa and larval stages was well landward of the upwelling front: generally, kilometers landward of the front. Hence, the dispersal of these larvae was not affected by the upwelling jet, which is present on the seaward side of the upwelling front (Huyer 1983). By avoiding the fast alongshore flow in the upwelling jet and, instead, remaining close to shore where the alongshore flow is slower, larvae will experience less alongshore transport. During upwelling, flow is to the south, but during downwelling or relaxation events, the flow often reverses and flows northward (Kundu \& Allen 1976, Send et al. 1987). Larvae in the very nearshore waters could, during their pelagic develop- 
ment, experience very much reduced alongshore transport. Shanks \& Eckert (2005) found that most California Current intertidal fishes and benthic crustaceans spawn primarily during the upwelling season. They suggested that this, as well as other life-history traits, may have evolved to exploit the north and south oscillation in flow associated with downwelling and upwelling and thereby limit the net alongshore transport of larvae.

As the upwelling season progresses, large eddies and offshore squirts form in the upwelling jet (Strub et al. 1991, Strub \& James 2000). These are apparent in the satellite image from 14 August (Fig. 2). Researchers hypothesize that these offshore jets may transport the larvae of coastal species far from shore (Sotka et al. 2004). The larvae of continental shelf fishes can be transported seaward in jets (Haury et al. 1986), but we know of no study that has demonstrated the same effect on the larvae of intertidal invertebrates. Current drifters released seaward of the upwelling front are often rapidly swept offshore by jets (Barth \& Smith 1998, Barth et al. 2000). Drifters released landward of the upwelling front, however, were not caught by jets and swept offshore, rather they drifted back toward the coast (Barth \& Smith 1998, Barth et al. 2000). Intertidal invertebrate larvae were caught well landward of the upwelling front and upwelling jet; hence, their dispersal should be unaffected by eddies and squirts.

Cross-shelf currents generated by upwelling and downwelling, either in the surface Ekman layer or in the flow below the Ekman layer, are much faster than larval swimming speeds, yet larvae were not pushed on- and offshore by upwelling and downwelling. Shanks \& Brink (2005) suggested the following hypothesis to this conundrum. They pointed out that coastal downwelling and upwelling are essentially convergent and divergent flow fields situated against a coast. Zooplankton is frequently concentrated by convergent flow (Franks 1992) and can also become concentrated at depth in divergent flow (Olsen \& Backus 1985). Models suggest that organisms that maintain a preferred depth in the face of vertical flow generated at a convergence or a divergence will become concentrated by and trapped in the flow field (Franks 1992). The divergence and convergence zones generated by upwelling and downwelling are located near the coast, and, hence, larvae concentrated in these flow fields can remain near the coast.

For this type of flow-mediated concentration to occur, larvae must swim faster than the vertical flow and they must be able to behaviorally maintain a preferred depth. Swimming speeds of intertidal invertebrate larvae are around 0.1 to $1 \mathrm{~cm} \mathrm{~s}^{-1}$ (Chia et al. 1984), while the vertical flows in upwelling and downwelling are around an order of magnitude slower (cf. Huyer 1983); most types of larvae are capable of swimming faster than the vertical flow in upwelling and downwelling. Numerous larvae have been found to respond to changes in pressure by swimming up or down (Kingsford et al. 2002). Genin et al. (2005) simultaneously measured the vertical displacement of individual zooplankters and vertical currents and found that zooplankton remained at a certain depth by swimming against upwelling and downwelling currents, but were carried along passively with horizontal flow. The swimming ability and behaviors, which Shanks \& Brink (2005) hypothesized are necessary for larvae to become concentrated in upwelling or downwelling zones, have been observed in a variety of mero- and holoplankton. This model suggests that by controlling their vertical position, larvae can exert control over their cross-shelf dispersal. The larvae were clearly not acting like passive particles in a flow field. We observed strong similarities in the patterns of distribution of different taxa and stages on a given day (Fig. 4). If these patterns are generated by the interaction of larval behavior with the flow field then this suggests that larval behavior is very similar across a number of taxa and stages.

Furthermore, surface Ekman transport diminishes as water depth becomes shallow (comparable to the Ekman depth) and stratification weakens (Austin \& Lentz 2002, Kirincich et al. 2005). In shallow regions (<50 m depth) and weakly stratified regions, the surface Ekman transport is reduced, because the Ekman Spiral is not able to fully manifest itself, either due to premature interaction with the bottom or an intersection with the bottom boundary layer and the attendant stresses. Without direct current measurements, we infer these impacts on Ekman transport from the vertical density structure. On 27 June, the density profile at the innermost station does not exhibit a clear surface or bottom boundary layer (Fig. 4), but rather a uniform, relatively weak stratification, suggesting that Ekman transport may have been impacted. However, on the other upwelling date (14 August), the density profiles at most nearshore stations exhibit a clear surface layer (Fig. 4), although the 2 and $5 \mathrm{~km}$ stations do not. For both downwelling dates (3 and 18 July), the density profiles at the most nearshore station exhibit surface layers, suggesting that the full Ekman transport may have been established at these points.

The most inshore station was in shallow water ( $<12 \mathrm{~m}$ deep) and close to the outer edge of the surf zone. In water this shallow, flow is dominated by the effect of waves (Lentz et al. 2008). Stokes drift (the slight movement of water in the direction of surface wave propagation) and breaking waves in the surf zone transport water at the surface shoreward. To compensate, water is carried seaward by the undertow. 
Within the surf zone, maximum offshore flow due to the undertow is found around the middle of the water column, while seaward of the surf zone the undertow current is strongest just below the surface (Lentz et al. 2008). Currents generated by the undertow dissipate at water depths $>12 \mathrm{~m}$. By avoiding the surface waters, larvae at the most nearshore station avoid the offshore transport due to the undertow; a consequence of the observed vertical distribution of the larvae is reduced offshore transport.

The results and conclusions from the present study are essentially identical to those from a study on the Atlantic coast of North America (Shanks \& Brink 2005, Shanks et al. 2002, 2003a) in which researchers identified a cluster of taxa, i.e. bivalves, the larvae of which remained within about $5 \mathrm{~km}$ of shore during upwelling and downwelling, a distribution identical to that reported in the current study. They, as well as other researchers (Ma \& Grassle 2004, Ma 2005), identified a second cluster of bivalve species, the larvae of which were found below the thermocline and moved shoreward with upwelling and seaward during downwelling. Morgan et al. (2009, in press) sampled the cross-shelf distribution of coastal invertebrate larvae off northern California, where upwelling favorable winds are more persistent and stronger than over the North Carolina or Oregon continental shelves. Their sample design was similar to that employed here, and their conclusions were identicali larvae of intertidal invertebrates were found in abundance within $6 \mathrm{~km}$ of shore, were rare offshore, and the larvae avoided the surface Ekman layer. The observations and conclusions from the study on the Atlantic coast (weak upwelling), research off northern California (strong upwelling; Morgan et al. 2009, in press), and the present study (moderate upwelling) are consistent; larvae of a variety of intertidal invertebrates were observed to avoid the surface Ekman layer and to remain close to shore $(<6 \mathrm{~km})$ throughout their development, during both upwelling and downwelling. The paradigm that upwelling transports larvae of intertidal organisms out to sea and away from settlement sites on the shore and downwelling transports them back toward shore is not supported by the data.

A number of studies of recruitment in intertidal barnacles and mussels have reported latitudinal variations in recruitment, which the authors have attributed to latitudinal variations in the strength and persistence of upwelling (Alexander \& Roughgarden 1996, Menge et al. 1997, Connolly et al. 2001, Broitman et al. 2005, 2008). For example, studies have found that the recruitment of barnacles in the intertidal zone is lower south of Cape Blanco in Oregon than to the north. The lower recruitment south of Cape Blanco is attributed to persistent upwelling transporting larvae away from coastal settlement sites. The higher recruitment to the north of the cape is attributed to intermittent upwelling; during upwelling the larvae are carried away from shore, but during relaxation events they are returned to shore, leading to higher settlement and, ultimately, higher recruitment. Obviously, if upwelling does not carry larvae offshore and downwelling does not carry them back toward shore, rather the larvae remain next to shore during both upwelling and downwelling, then the proposed explanation for latitudinal variation in recruitment fails; the larvae of intertidal invertebrates remained close to shore in our samples off Oregon and in those collected by Morgan et al. (2009, in press) off northern California. In fact, on all our sampling dates, a large percentage of the larvae were within $1 \mathrm{~km}$ of shore during upwelling and downwelling.

In the samples collected off North Carolina, northern California, and Oregon, larvae of intertidal invertebrates were not going through their development far from shore; larvae in all stages of development, including competent larvae, were present in high abundance from just outside the surf zone to only a few kilometers offshore. For larvae to return to shore and settle, they need not be transported shoreward very far, perhaps only $100 \mathrm{~s}$ of meters to $1 \mathrm{~km}$. Due to this distribution of larvae, connectivity between populations of intertidal organisms will be governed by larval transport in currents immediately adjacent to shore. Larvae are inhabiting waters close to shore where flow will be strongly affected by coastal topography, the shoaling bottom, and surf zone dynamics. To understand the dynamics of larval supply to the intertidal and shallow subtidal zones, we need to focus on the interaction of larvae with the hydrography of the very nearshore waters, i.e. the waters between the shore and a couple of kilometers to sea that have received comparatively little study by physical or biological oceanographers. There are a few examples of studies that have examined larvae in these very nearshore waters (Alldredge \& Hamner 1980, Archambault et al. 1998, Archambault \& Bourget 1999, McCulloch \& Shanks 2003, Shanks \& McCulloch 2003, Shanks et al. 2003b), but we are obviously at the very beginning of our work on this part of the ocean. Of particular importance to the onshore migration of competent larvae may be transport from the nearshore waters into and then across the surf zone. This is an area of the ocean that has received very little attention from biological oceanographers.

Acknowledgements. The present research was funded by a National Science Foundation Small Grant for Exploratory Research (OCE 0715425). Sampling assistance was provided by Erin Cooper and Larry Draper, the captain of the OIMB's research vessel. 


\section{LITERATURE CITED}

Alexander SE, Roughgarden J (1996) Larval transport and population dynamics of intertidal barnacles: a coupled benthic/oceanic model. Ecol Monogr 66:259-275

Alldredge AL, Hamner WM (1980) Recurring aggregation of zooplankton by tidal current. Estuar Coast Mar Sci 10: 31-37

Archambault P, Bourget E (1999) Influence of shoreline configuration on spatial variation of meroplanktonic larvae, recruitment and diversity of benthic subtidal communities. J Exp Mar Biol Ecol 238:161-184

Archambault P, Roff JC, Bourget E, Bang B, Ingram GR (1998) Nearshore abundance of zooplankton in relation to shoreline configuration and mechanisms involved. J Plankton Res 20:671-690

Austin JA, Barth JA (2002) Variations in the position of the upwelling front on the Oregon shelf. J Geophys Res 107: $1-15$

Austin JA, Lentz SJ (2002) The inner shelf response to winddriven upwelling and downwelling. J Phys Oceanogr 32: 2171-2193

Barber RT, Smith RL (1981) Coastal upwelling. In: Longhurst A (ed) Analysis of marine ecosystems. Academic Press, London, p 31-67

Barth JA, Smith RL (1998) Separation of a coastal upwelling jet at Cape Blanco, Oregon, USA. S Afr J Mar Sci 19:5-14

> Barth J, Pierce S, Smith R (2000) A separating coastal upwelling jet at Cape Blanco, Oregon and its connection to the California Current System. Deep-Sea Res II 47: 783-810

Broitman BR, Navarrete SA, Smith F, Gaines SD (2001) Geographic variation in southeastern Pacific intertidal communities. Mar Ecol Prog Ser 224:21-34

Broitman B, Blanchette C, Gaines S (2005) Recruitment of intertidal invertebrates and oceanographic variability at Santa Cruz Island, California. Limnol Oceanogr 50:1473-1479

Broitman BR, Blanchette CA, Menge BA, Lubchenco J and others (2008) Spatial and temporal patterns of invertebrate recruitment along the west coast of the United States. Ecol Monogr 78:403-421

Chia FS, Buckland-Nicks J, Young CM (1984) Locomotion of marine invertebrate larvae: a review. Can J Zool 62: 1205-1222

Connolly RS, Roughgarden J (1999) Increased recruitment of northeastern Pacific barnacles during the 1997 El Nino. Limnol Oceanogr 44:466-469

Connolly SR, Menge BA, Roughgarden J (2001) A latitudinal gradient in recruitment of intertidal invertebrates in the northeast Pacific Ocean. Ecology 82:1799-1813

Farrell TM, Bracher D, Roughgarden J (1991) Cross-shelf transport causes recruitment to intertidal populations in central California. Limnol Oceanogr 36:279-288

Faul F, Erdfelder E, Land AG, Buchner A (2007) G*Power3: a flexible statistical power analysis program for the social, behavioral and biomedical sciences. Behav Res Methods 39:175-191

Franks PJS (1992) Sink or swim: accumulation of biomass at fronts. Mar Ecol Prog Ser 82:1-12

Garland ED, Zimmer CA, Lentz SJ (2002) Larval distributions in inner-shelf waters: the roles of wind-driven cross-shelf currents and diel vertical migrations. Limnol Oceanogr 47:803-817

- Genin A, Jaffe JS, Reef R, Richter C, Franks PJS (2005) Swimming against the flow: a mechanism of zooplankton aggregation. Science 308:860-862

Haury LR, Pelaez J, Koblinsky CJ, Wiesenhahan D (1986)
Biological consequences of a recurrent eddy off Point Conception, California. J Geophys Res 91:12937-12956

Huyer A (1983) Coastal upwelling in the California current system. Prog Oceanogr 12:259-284

Kingsford M, Leis J, Shanks A, Lindeman K, Morgan S, Pineda J (2002) Sensory environments, larval abilities and local self-recruitment. Bull Mar Sci 70:309-340

Kirincich A, Barth J, Grantham B, Menge B, Lubchenco J (2005) Wind-driven inner-shelf circulation off central Oregon during summer. J Geophys Res 110, C10S03, doi:10. 1029/2004JC002611

Kundu P, Allen J (1976) Some three-dimensional characteristics of low frequency current fluctuations near the Oregon coast. J Phys Oceanogr 6:181-199

Lentz SJ, Fewlin M, Howd P, Fredericks J, Hathaway K (2008) Observations and a model of undertow over the inner continental shelf. J Phys Oceanogr 38:2341-2357

> Ma H (2005) Spatial and temporal variation in surfclam (Spisula solidissima) larval supply and settlement on the New Jersey inner shelf during summer upwelling and downwelling. Estuar Coast Shelf Sci 62:41-53

Ma H, Grassle JP (2004) Invertebrate larval availability during summer upwelling and downwelling on the inner continental shelf off New Jersey. J Mar Sci 62:837-865

$>$ McCulloch A, Shanks AL (2003) Topographically generated fronts, very nearshore oceanography and the distribution and settlement of mussel larvae and barnacle cyprids. J Plankton Res 25:1427-1439

Menge BA, Daley BA, Wheeler PA, Strub PT (1997) Rocky intertidal oceanography: an association between community structure and nearshore phytoplankton concentration. Limnol Oceanogr 42:57-66

Morgan SG, Fisher JL, Mace AJ, Akins L, Slaughter AM, Bollens SM (2009) Cross-shelf distributions and recruitment of crab postlarvae in a region of strong upwelling. Mar Ecol Prog Ser 380:173-185

Morgan SG, Fisher JL, Miller SH, McAfee ST, Largier JL (in press) Nearshore larval retention in a region of strong upwelling and recruitment limitation. Ecology

Morris RH, Abbott DP, Haderlie EC (1980) Intertidal invertebrates of California. Stanford University Press, Stanford, CA

Olsen DB, Backus RH (1985) The concentrating of organisms at fronts: a coldwater fish and a warm-core Gulf Stream ring. J Mar Res 43:113-137

Omori M, Ikeda T (1984) Methods in marine zooplankton ecology. John Wiley \& Sons, New York

$>$ Peterson WT, Miller CB, Hutchinson A (1979) Zonation and maintenance of copepod populations in the Oregon upwelling zone. Deep-Sea Res 26:467-494

Poulin E, Palma AT, Leiva G, Narvaez D, Pacheco R, Navarrete SA, Castilla JC (2002) Avoiding offshore transport of competent larvae during upwelling events: the case of the gastropod Concholepas concolepas in Central Chile. Limnol Oceanogr 47:1248-1255

Rilov G, Dudas S, Menge B, Grantham B, Lubchenco J, Schiel D (2008) The surf zone: a semi-permeable barrier to onshore recruitment of invertebrate larvae? J Exp Mar Biol Ecol 361:59-74

Roughgarden J, Gains SD, Possingham H (1988) Recruitment dynamics in complex life cycles. Science 241:1460-1466

Send U, Beardsley RC, Winant CD (1987) Relaxation from upwelling in the Coastal Ocean Dynamics Experiment. J Geophys Res 92:1683-1698

Shanks AL (ed) (2001) An identification guide to the larval marine invertebrates of the Pacific Northwest. Oregon State University Press, Corvallis, OR 
Shanks AL, Brink L (2005) Upwelling, downwelling, and cross-shelf transport of bivalve larvae: test of a hypothesis. Mar Ecol Prog Ser 302:1-12

Shanks AL, Eckert G (2005) Life-history traits and population persistence of California Current fishes and benthic crustaceans; solution of a marine drift paradox. Ecol Monogr 75:505-524

Shanks AL, McCulloch A (2003) Topographically generated fronts, very nearshore oceanography, and the distribution of chlorophyll, detritus, and selected diatom and dinoflagellate taxa. Mar Biol 143:969-980

Shanks AL, Largier J, Brink L, Brubaker J, Hooff R (2000) Demonstration of the onshore transport of larval invertebrates by the shoreward movement of an upwelling front. Limnol Oceanogr 45:230-236

Shanks AL, Largier J, Brink L, Brubaker J, Hooff R (2002) Observations on the distribution of meroplankton during a downwelling event and associated intrusion of the Chesapeake Bay estuarine plume. J Plankton Res 24:391-416

Shanks AL, Largier J, Brubaker J (2003a) The nearshore distribution of larval invertebrates during an upwelling event. J Plankton Res 25:645-667

Shanks AL, McCulloch AA, Miller J (2003b) Topographically

Editorial responsibility: Paul Snelgrove,

St. John's, Newfoundland, Canada generated fronts, very nearshore oceanography and the distribution of larval invertebrates and holoplankters. J Plankton Res 25:1251-1277

Sotka EE, Wares JP, Barth JA, Grosberg RK, Palumbi SR (2004) Strong genetic clines and geographic variation in gene flow in the rocky intertidal barnacle Balanus glandula. Mol Ecol 13:2143-2156

Strub PT, James C (2000) Altimeter-derived variability of surface velocities in the California Current System. 2. Seasonal circulation and eddy statistics. Deep-Sea Res II 47: 831-870

Strub P, Allen J, Huyer A, Smith R (1987a) Large-scale structure of the spring transition in the coastal ocean off western North America. J Geophys Res 92:1527-1544

Strub PT, Allen JS, Huyer A, Smith RL (1987b) Seasonal cycles in currents, temperature, winds, and sea level over the Northeast Pacific continental shelf: $35^{\circ} \mathrm{N}$ to $48^{\circ} \mathrm{N}$. J Geophys Res 92:1507-1526

Strub PT, Kosro PM, Huyer A (1991) The nature of cold filaments in the California Current system. J Geophys Res 96: 14693-14706

Venrick EL (1978) How many cells to count? In: Sournia A (ed) Phytoplankton manual. UNESCO, Paris, p 167-180

Submitted: November 27, 2008; Accepted: March 31, 2009

Proofs received from author(s): June 12, 2009 